\begin{tabular}{c|c|c}
\hline \hline & DISEASES OF AQUATIC ORGANISMS \\
Vol. 48: 197-207, 2002 & Dis Aquat Org & Published April 5 \\
\hline \hline
\end{tabular}

\title{
Site preference of fish myxosporeans in the gill
}

\author{
Kálmán Molnár* \\ Veterinary Medical Research Institute, Hungarian Academy of Sciences, PO Box 18, 1581 Budapest, Hungary
}

\begin{abstract}
In addition to the morphological and size characteristics of the spores, indicating the exact location and tissue specificity is also essential for differentiation of the large number of species belonging to the group of gill-parasitic fish, the myxosporeans. According to the observations of the present author, Myxobolus, Henneguya and Thelohanellus species are characterised by strict tissue specificity, and species showing affinity to the epithelium, connective tissue, cartilage or vascular tissue usually occur in a strictly defined location within the gill apparatus. Some of the species typically form plasmodia in the lamellae of the gill and others in the gill filaments. Yet other species develop their plasmodia at the base of the gill filament or in the gill arch. Instead of the generally accepted but misleading terms 'intra-' and 'interlamellar', the present author distinguishes interlamellar-epithelial and intralamellar-vascular types in the case of plasmodia developing in the gill lamellae, and intrafilamental-epithelial, intrafilamental-vascular and intrafilamental-chondroidal types in the case of plasmodia developing in the gill filaments. Regarding site of development within the gill, the location of basifilamental plasmodia and that of plasmodia developing in the cartilaginous matrix, connective tissue or blood vessels of the gill arch are well distinguishable from the above types. The different types and their variations are shown in histological illustrations.
\end{abstract}

KEY WORDS: Myxosporea $\cdot$ Henneguya $\cdot$ Myxobolus $\cdot$ Thelohanellus $\cdot$ Site selection $\cdot$ Terminology

Resale or republication not permitted without written consent of the publisher

\section{INTRODUCTION}

The majority of the 2 largest genera of myxosporeans, Myxobolus and Henneguya, including about 450 and 120 species respectively, have been described on the basis of spore morphology without data on vegetative stages, and reliable data can scarcely be found on their location within the host and on tissue specificity. For gill-parasitic species, the descriptions mostly mention only the gill as such, and the actual location within the gill is rarely indicated. The gill as a body part most commonly affected by myxosporeans is a rather complex organ. Besides the cartilaginous, sometimes osseous, solid gill arch, it contains gill filaments consisting of cartilaginous, fibrous and epithelial elements. It constitutes the hemibranchia, as well as gill lamellae (respiratory plates) that are separated from the surroundings by an epithelial and an endothelial layer. Among the gill-parasitic myxosporean species,

*E-mail: kalman@vmri.hu plasmodia developing in the thick cartilage layer should be judged entirely differently from those formed in the stratified epithelium or in the capillaries of the respiratory lamellae. Indicating the location of the myxosporeans precisely is made difficult by the lack of uniformity in the designation of the gill components. In the interpretation of many authors, the term 'gill arch' means only the cartilaginous structure of the gill arch, the blood vessels running in it, and the surrounding fibrous and epithelial elements, while others define it as the hemibranchia including the primary lamellae or filaments. Especially confusing are the terms 'primary lamellae' and 'secondary lamellae', which can be replaced by the words 'filaments' and 'lamellae'. The term 'lamella' creates difficulties primarily in parasitological research, since it is difficult to define whether the terms 'inter-' and 'intralamellar' locations introduced by Current \& Janovy (1978) relate to occurrence in the primary or in the secondary lamellae.

Few specialists have dealt with the diverse locations of gill colonisation by myxosporeans. Of them, 
Paperna (1973), Cone \& Wiles (1985), Sakiti et al. (1991), Bahri \& Marques (1996), and Molnár \& Székely (1999) supplied data on the site selection of individual species. The above authors differentiated types of development on the gill arch, gill filaments and gill lamellae. However, in most species descriptions, only a few papers precisely indicated the site of development, and even the majority of authors dealing with pathology failed to go further than assigning the species that formed plasmodia on the gill filaments to either the intra- or the interlamellar developmental type introduced by Current \& Janovy (1978).

The objective of this paper is to call the attention of myxosporean specialists to the importance of precise site indication, and to propose, on the basis of $30 \mathrm{yr}$ of experience and histopathological studies, a uniform system for indicating the most important type locations.

\section{MATERIALS AND METHODS}

Records of gill infections with myxosporean parasites over a $30 \mathrm{yr}$ period were evaluated, and the site selection of different species was typed. Preparations were selected from the author's histological collection made during a more than $30 \mathrm{yr}$ period of work on fish myxosporeans. Histological sections were made from the gills of various fish species infected by different developmental stages of Myxobolus, Henneguya and Thelohanellus species. To ensure a good plane of sectioning on the hemibranchia, the gill arches of infected fish, with the intact holobranchs, were individually separated and gently placed under a coverslip soaked for $5 \mathrm{~min}$ in some drops of Bouin's solution. After the gill filaments became rigid and preserved their structure in a flat plane, the gills were transferred into bottles and fixed for $4 \mathrm{~h}$ in a larger amount of Bouin's solution. Gills embedded in paraffin wax were cut in 4 to $8 \mu \mathrm{m}$ sections, and stained with haematoxylin and eosin. Microscopic photos and digitalised pictures were prepared.

\section{RESULTS}

The Myxosporea species forming large plasmodia were located on the gills at diverse sites typical of the species (Fig. 1). They included species developing in the cartilaginous gill arch, at the base of gill filaments, in the unlamellated parts of the gill filaments and in the gill lamellae. The following typical locations were the most common.

\section{Infection associated with the gill lamellae (lamellar type)}

Interlamellar type

In this type of infection (Fig. 1; $\mathrm{LE}_{1}, \mathrm{LE}_{2}$ ), represented by Myxobolus pavlovskii, a parasite of the bighead and silver carp, the plasmodia developed in the stratified epithelium between the gill lamellae and the developing parasites were located between 2 neighbouring lamellae. In the majority of cases the plasmodia filled only the interlamellar space (small-cyst type; Fig. 2), while in others, larger plasmodia pushed aside some adjacent gill lamellae and appeared in large-cyst form (Fig. 3).

\section{Intralamellar type}

In this type of infection, which proved to be the most common location for the gill-parasitic myxosporeans studied, the plasmodia formed in the vascular network of the gill lamellae, and a plasmodium of small or larger size appeared within a single lamella. This type could be divided into 3 subtypes.

Small-cyst, central type (Fig. $1 ; \mathrm{LV}_{1}$ ): The plasmodium was located centrally in the gill lamella, dilating the latter symmetrically towards both sides. This type is represented by the development of some Henneguya species, such as $H$. creplini (Fig. 4).

Small-cyst, asymmetric type (Fig. $1 ; \mathrm{LV}_{2}$ ) This type is characterised by the development of plasmodia on one side of the gill lamella (Fig. 5), resulting in marked dilatation of the latter on that side. The plasmodium developing in the gill lamella fills the space between 2 neighbouring gill lamellae. The plasmodium is separated from the external world and from the intact epithelial cells by only a thin epithelial or endothelial fold. On the less affected side of the gill lamella, the red blood cells flowing in the remnants of the capillary network, among the pillar cells, are easily discernible. A typical example of this type is the development of Myxobolus bramae. In chronic cases, when the growing plasmodium protrudes into the interlamellar space and causes epithelial cell destruction, the plasmodium seems to be located between lamellae and, in the case of mature plasmodia, it is difficult to distinguish from the interlamellar type (Fig. 6).

Large-cyst type (Fig. $1 ; \mathrm{LV}_{3}$ ): Occasionally, both of the former types can give rise to large plasmodia that exceed the length of the gill lamella or the size of the interlamellar space between 2 neighbouring gill lamellae. Such plasmodia deform and push sideways some gill lamellae on both sides (Figs. $7 \&$ 8). Very often the wall of the parasitised gill lamella, consisting of an 


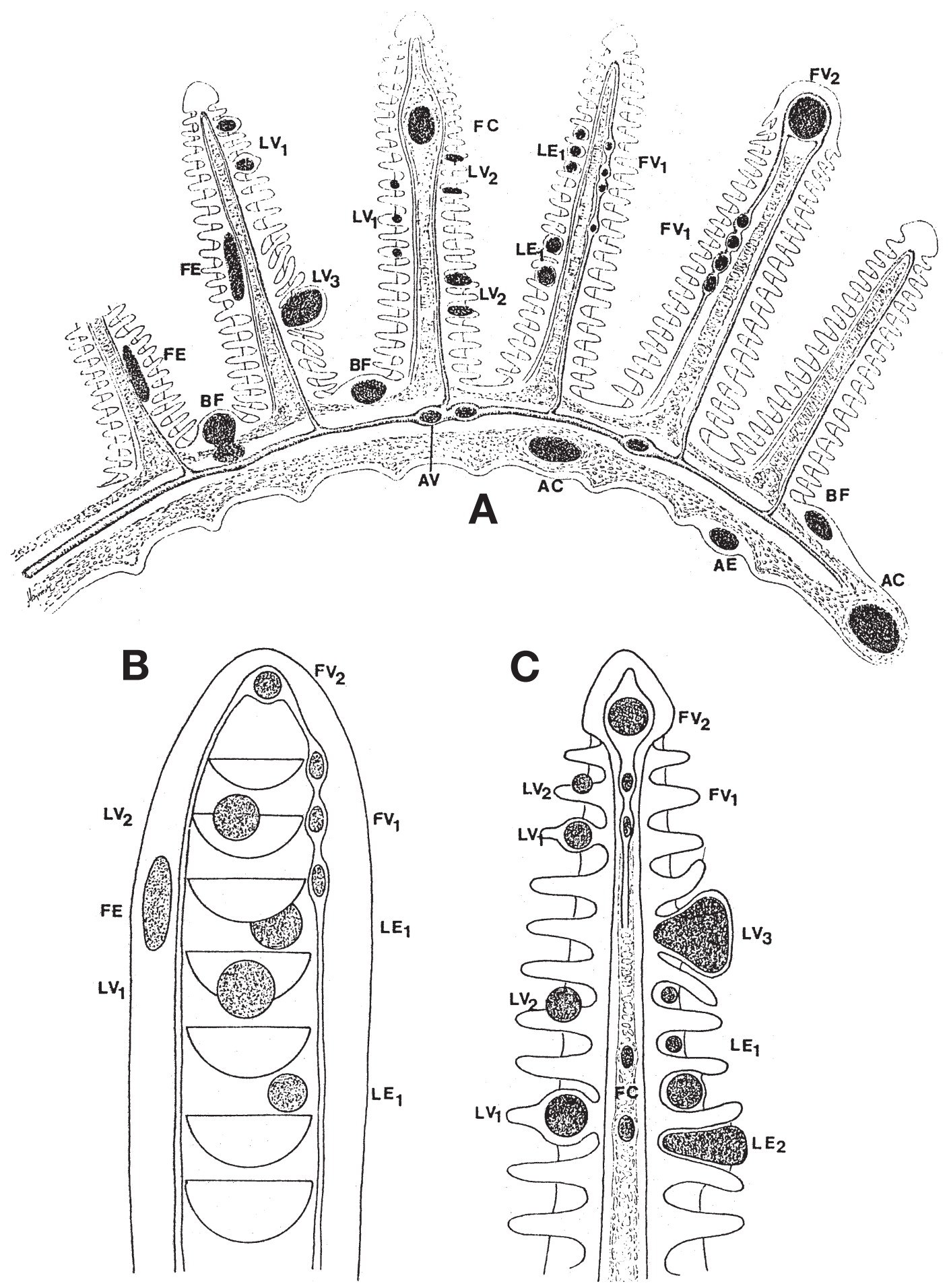

Fig. 1. Location of Myxosporea plasmodia in different areas of the gill. (A) Gill arch with gill filaments and gill lamellae; (B) A gill filament in frontal view; (C) A gill filament in lateral view. There are 4 types of plasmodia. I. Plasmodia in the gill lamellae, classified as (1) interlamellar-epithelial type (LE): Small plasmodia $\left(\mathrm{LE}_{1}\right)$ and large plasmodium deforming several gill lamellae (LE $)_{2}$; (2) Intralamellar-vascular type (LV): Plasmodium located centrally in the gill lamellae $\left(\mathrm{LV}_{1}\right)$, plasmodium protruding from one side of the gill lamella $\left(\mathrm{LV}_{2}\right)$ and large plasmodium deforming several gill lamellae $\left(\mathrm{LV}_{3}\right)$. II. Plasmodia in the gill filaments, classified as (1) intrafilamental-epithelial type (FE); (2) intrafilamental-vascular type (FV): small round or elongated plasmodia in the afferent artery $\left(\mathrm{FV}_{1}\right)$ and large plasmodia formed by the fusion of several plasmodia near the end of the gill filament (FV $\mathrm{V}_{2}$; (3) intrafilamental-cartilage type (FC). III. Basifilamental plasmodium type (BF). IV. Plasmodia located in the gill arch, classified as (1) plasmodia developing in the cartilaginous structure of the gill arch (AC); (2) plasmodia developing in the blood vessels of the gill arch $(\mathrm{AV})_{;}(3)$ plasmodia developing in the epithelial or connective tissue elements of the gill arch (AE) 


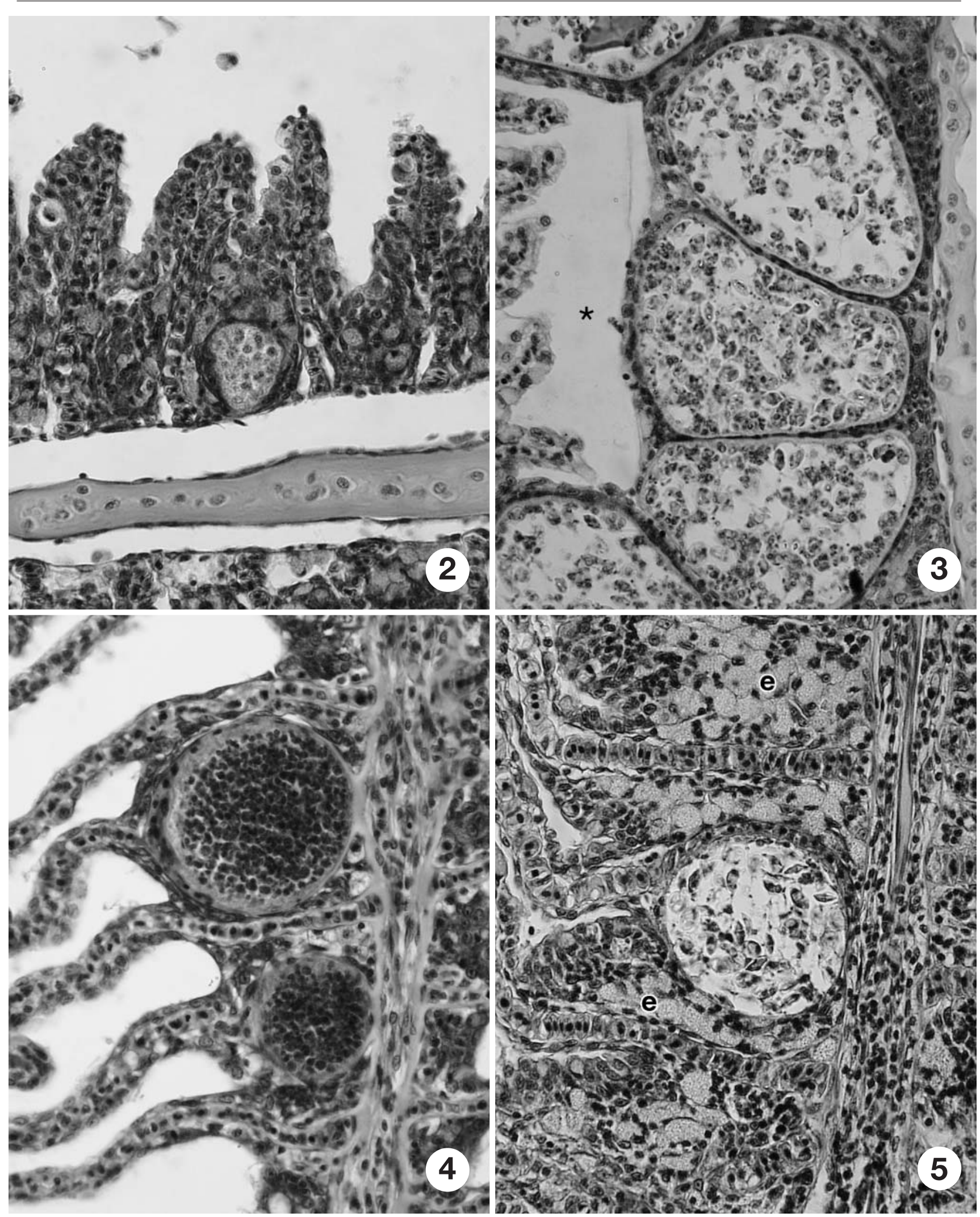

Figs. 2 to 5. Fig. 2. Plasmodium of Myxobolus pavlovskii developing in the epithelium between the gill lamellae. The young plasmodium located in the stratified epithelium is surrounded by epithelial cells and pseudoeosinophil cells. Haematoxylin and eosin (H\&E). $\times 500$. Fig. 3. Plasmodia of Myxobolus pavlovskii starting their development in the epithelium between the gill lamellae and deforming the neighbouring gill lamellae. The plasmodia containing mature spores are separated from the interfilamental space by a thin epithelial layer only (*). H\&E. $\times 400$. Fig. 4. Plasmodium of Henneguya creplini developing in the gill lamella. The plasmodia are located in the capillary lumen directly at the base of the filaments, causing symmetric dilatation of the blood vessels. H\&E. $\times 500$. Fig. 5. Plasmodium of Myxobolus bramae developing in the gill lamella. The plasmodium occupies only one side of the lamella, while on the other side the flow of blood cells is unobstructed. There are numerous pseudoeosinophil cells (e) in the interlamellar epithelium. H\&E. $\times 500$ 

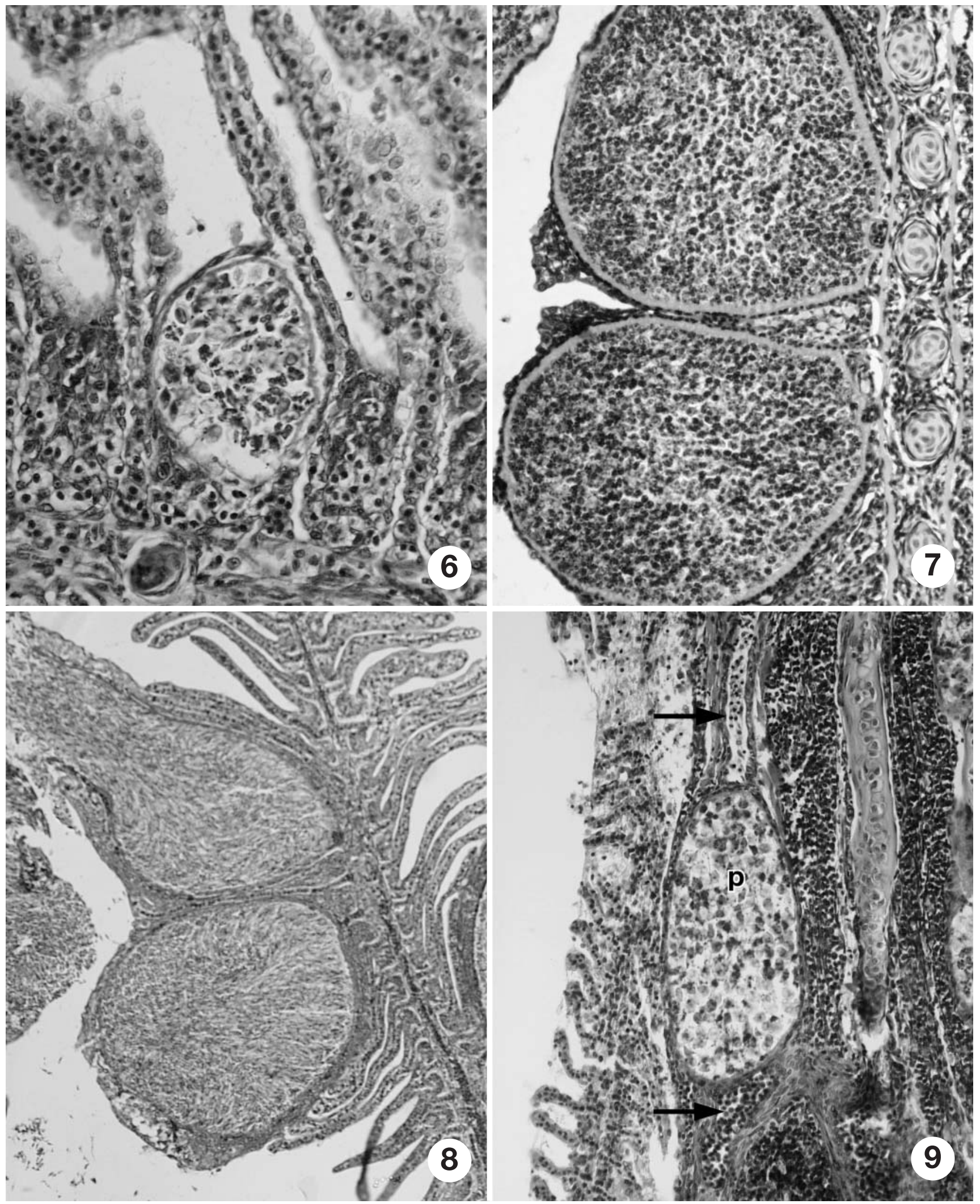

Figs. 6 to 9. Fig. 6. Large, spore-containing plasmodium of Myxobolus bramae in the vasculature of the gill lamella. The asymmetrically protruding plasmodium is contiguous with the neighbouring gill lamella and occupies a seemingly interlamellar position. H\&E. $\times 500$. Fig. 7. Plasmodia of Myxobolus hungaricus developing in the gill lamella. The original structure of the attacked gill lamella is no longer discernible. The wall of the plasmodium is constituted by 2 neighbouring gill lamellae each. H\&E. $\times 200$. Fig. 8 . Plasmodia of Henneguya sp. developing in the gill lamella of Zingel zingel, containing mature spores. One of the plasmodia has just ruptured and is releasing its spores to the exterior. The plasmodia have been formed in the vasculature of a single gill lamella, but the large plasmodia have deformed the neighbouring gill lamellae and pushed them side. H\&E. $\times 130$. Fig. 9. Myxobolus margitae plasmodium (p) developing in the gill filament of bleak (Alburnus), in the afferent artery (arrows) filled with blood cells. H\&E. $\times 300$ 


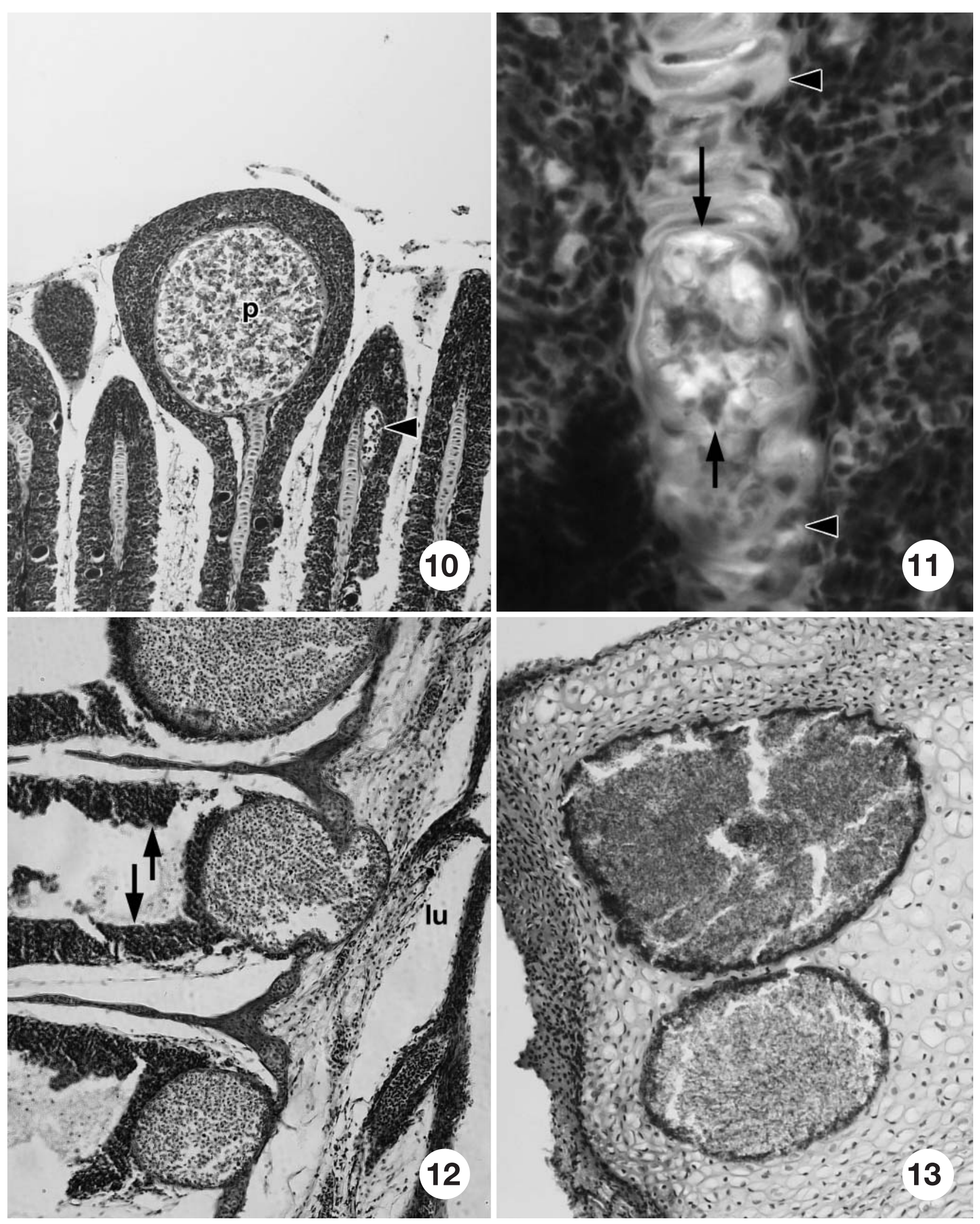

Figs. 10 to 13. Fig. 10. Large plasmodium of Myxobolus dispar (p) in the afferent artery at the end of the gill filament of common carp. The artery of the neighbouring gill filament contains another, smaller plasmodium (arrow). H\&E. $\times 300$. Fig. 11. Small plasmodium of Myxobolus sp. (arrows) containing some spores and developing in the cartilaginous structure of the gill filament (open arrows) of roach. H\&E. $\times 1000$. Fig. 12. Plasmodia of Myxobolus basilamellaris under the epithelial layer of the gill filaments (arrows). The plasmodium may form a sac-like protrusion into the lumen of the gill arch (lu). H\&E. $\times 130$. Fig. 13. Plasmodia of Myxobolus intrachondrealis in the cartilage forming the end of the gill arch. H\&E. $\times 250$ 
epithelial-endothelial duplex fold, becomes so thin that it can no longer be discerned histologically, and the wall is formed by the 2 neighbouring lamellae (Fig. 7). In such cases the initial stage of plasmodium development can be inferred from the remnants of the capillary (Fig. 8) that enters the lamellae from the gill filament.

In the majority of the cases studied the infections localised in the gill lamellae were independent of the location along the gill filament. However, in the case of the bream parasite Myxobolus hungaricus the plasmodia typically infected lamellae located in the central and basal part of the filaments, while in the case of $M$. bramae and $M$. macrocapsularis parasitising the same fish species, most of the plasmodia were detected in lamellae close to the apical end of the gill filament.

A special form of intralamellar location was observed in the case of the plasmodium of Myxobolus persicus, which started to develop between the endothelial and epithelial layer of the gill lamellae; as a result, the capillary devoid of epithelium was easily discernible within the plasmodium (see Masoumian et al. 1994).

\section{Infection associated with the gill filaments (filamental type)}

\section{Filamental, vascular type}

This type (Fig. 1; FV) proved to be one of the commonest types of plasmodium development. Numerous Myxobolus species including $M$. bramae, M. macrocapsularis and $M$. dispar develop in this way (Fig. 1; $\mathrm{FV}_{1} ;$ Fig. 9). The plasmodia colonising the gill accumulate in the afferent artery of the gill filaments, and the fusion of several plasmodia often produces a large plasmodium at the end of the filaments. The size of that plasmodium may exceed the width of the gill filaments (Fig. 1, FV ${ }_{2}$; Fig. 10).

\section{Filamental, epithelial type}

In this case (Fig. 1; FE) the large plasmodia are formed in the stratified epithelium of the filament, in areas devoid of lamellae, rather than in the interlamellar epithelium. This type of infection has occasionally been observed in several unidentified species; however, we do not possess appropriate documentation to support this.

\section{Filamental, intrachondreal type}

This type (Fig. 1; FC) was observed on a single occasion in the gills of Rutilus rutilus, in a not precisely identified Myxobolus species (Fig. 11), when the plasmodia were formed in the cells of the cartilaginous supporting layer of the gill filaments.

\section{Basifilamental type}

The plasmodia of the basifilamental type (Fig. 1; BF) developed in the subepithelial tissue between the gill filaments, on the surface of the gill arch, and often formed a plasmodium segment that penetrated into the cavity of the gill arch (Fig. 12). In the case of Myxobolus basilamellaris, illustrating this type of development, tissue affinity could not be determined precisely, although it is presumably associated with the compact connective tissue.

\section{Infections associated with the gill arch (gill arch type)}

Only a single form of gill arch infection (Fig. 1; AC), i.e. the infection of the cartilaginous gill arch, was recorded in the test material. A typical example was Myxobolus intrachondrealis developing in the cartilaginous matrix of the gill arch (Fig. 1; AC; Fig. 13). Data from the literature (Sakiti et al. 1991) suggest that types developing in the epithelium, blood vessels (Fig. 1; AE, AV) and connective tissue elements of the gill arch also occur.

\section{DISCUSSION}

Comparative evaluation of histological sections made from cases of gill parasitosis in the framework of myxosporean research conducted at the Veterinary Medical Research Institute of the Hungarian Academy of Sciences for several years showed the existence of diverse parasite locations within the gill. Consequently, describing the location of gill infection with a single word, e.g. the gill, provides very little information on parasite site selection. Knowledge of the actual site of establishment of the parasite in the gill may also facilitate the identification of parasite species; therefore, indicating the precise location of plasmodium development is indispensable for species descriptions.

Up to now, few specialists have provided exact data on the location of different Myxosporea species within the gill (Table 1), and even in these works the enclosed figures and photographs mostly provide specific information. The importance of precisely specifying the location within the gill was first pointed out by Paperna (1973), who, studying the infection of different African fish species, found that certain myxosporean species typically developed in the gill lamellae, others in the 
Table 1. Types of gill location of Henneguya, Myxobolus and Thelohanellus species on the basis of data listed from various sources. ${ }^{*}$ Well-defined location, ? = probable location

\begin{tabular}{|c|c|c|c|c|c|c|c|c|}
\hline \multirow{2}{*}{ Source } & \multirow[t]{2}{*}{ Parasite } & & \multicolumn{3}{|c|}{ - Type of infection } & \multirow[b]{2}{*}{$\begin{array}{l}\text { Basi- } \\
\text { filamental }\end{array}$} & \multirow[b]{2}{*}{$\begin{array}{l}\text { Arch-type } \\
\text { chondreal }\end{array}$} \\
\hline & & $\begin{array}{r}\text { Lam } \\
\text { Inter }\end{array}$ & $\begin{array}{l}\text { nellar } \\
\text { - Intra- }\end{array}$ & $\overline{\text { Vascular }}$ & $\begin{array}{l}\text { Filamental } \\
\text { Epithelial }\end{array}$ & $\overline{\text { chondreal }}$ & & \\
\hline \multirow[t]{2}{*}{ Bahri \& Marques (1996) } & Myxobolus bizerti & & & $?$ & $?$ & & & \\
\hline & M. ichkeulensis & & & & & & & $?$ \\
\hline Bahri et al. (1996) & Henneguya sp. & & * & & & & $?$ & \\
\hline Casals et al. (1997) & H. striotata & & * & & & & & \\
\hline Cone (1979) & H. doori & & & & $?$ & & & \\
\hline \multirow[t]{2}{*}{ Cone \& Wiles (1985) } & Myхobolus sp. I. & & & & & & & \\
\hline & Myхоbolus sp. II. & & & & & & * & \\
\hline Current \& Janovy (1978) & H. exilis & * & & & * & & & \\
\hline Dyková \& Lom (1978) & Thelohanellus pyriformis & & & * & & & & \\
\hline Haaparanta et al. (1994) & H. creplini & & * & * & & & & \\
\hline Hoffman et al. (1965) & M. cartilaginis & & & & & & & * \\
\hline Kalavati \& Narasimhamurti (1985) & H. waltairensis & & * & & & & & \\
\hline Kalavati \& Vaidehi (1991) & T. chilkensis & & * & & & & & \\
\hline Kovács-Gayer \& Molnár (1983) & M. basilamellaris & & & & & & * & \\
\hline Landsberg (1993) & M. centropomi & * & & & & & & \\
\hline Lom \& Molnár (1983) & M. basilamellaris & & & & & & * & \\
\hline \multirow[t]{2}{*}{ Masoumian et al. (1994) } & M. karuni & & & * & & & & \\
\hline & M. persicus & & * & & & & & \\
\hline McCraren et al. (1975) & Henneguya sp. & & * & & & & & \\
\hline Molnár (1979) & M. pavlovskii & * & & & & & * & \\
\hline Molnár (1998) & H. creplini & & * & & & & & \\
\hline Molnár (2000a) & M. intrachondrealis & & & & & & & * \\
\hline Molnár (2000b) & M. margitae & & * & & & & & \\
\hline Molnár \& Baska (1999) & M. hungaricus & & $*$ & & & & & \\
\hline \multirow[t]{2}{*}{ Molnár et al. (1996) } & M. shadgani & & & & & * & & \\
\hline & M. sharpeyii & & & & & & & * \\
\hline \multirow[t]{3}{*}{ Molnár \& Székely (1999) } & M. bramae & & * & * & & & & \\
\hline & M. macrocapsularis & & * & * & & & & \\
\hline & M. impressus & $*$ & & & & & & \\
\hline Mitchell (1989) & M. dujardini & & * & & & & & \\
\hline Obiekezie \& Enyenihi (1988) & H. chrysichthyi & * & & & & & & \\
\hline Paperna (1973) & Myxobolus spp. & $?$ & & $?$ & $?$ & $?$ & $?$ & $?$ \\
\hline Roubal (1994) & Henneguya sp. & & & & & & & * \\
\hline \multirow[t]{6}{*}{ Sakiti et al. (1991) } & M. dossoui & & & & & & & * \\
\hline & M. sarotherodoni & & & & & & & * \\
\hline & M. nokoueensis & & & & & & & * \\
\hline & M. barbi & & & & & & & \\
\hline & M. microcapsularis & & & & & & & $*$ \\
\hline & M. zillii & & $?$ & $?$ & $?$ & & & \\
\hline Sanaullah \& Ahmed (1980) & Myхobolus sp. & & $*$ & $*$ & & & & \\
\hline Shariff (1982) & H. shaharini & & * & $*$ & & & & \\
\hline Yokoyama et al. (1997) & M. koi & & * & $?$ & $?$ & & & \\
\hline
\end{tabular}

gill filaments and yet others at the base of the filaments or in the gill arch. Unfortunately, Paperna (1973) paid little attention to tissue locations and failed to differentiate types of development in the epithelium or in the blood vessels in cases of infection involving the gill lamellae or the gill filaments. Sakiti et al. (1991) also studied African fish species and identified as gill parasites 6 out of the 9 Myxobolus species studied. These included types developing in the gill filaments, in the gill lamellae and on the gill arch alike. Although the above authors did not specify the tissue specificity of the species developing on the gill filaments and gill lamellae, in addition to detecting the species Мyхobolus dossoui and M. sarotherodoni from the cartilage of the gill arch, they indicated the connective tissue layer of the gill arch as a location for the species $M$. nokoueensis and M. microcapsularis.

Recognising the importance of tissue location within the gill, while studying the species Henneguya exilis, Current \& Janovy (1978) introduced the concept of inter- and intralamellar infection, which is still widely used by researchers. These terms differ in their mean- 
ing from those proposed by the present author, as Current \& Janovy (1978) failed to distinguish between infections extending to the gill filament and those restricted to the gill lamellae. Although in the case of infection designated by them as intralamellar, Current \& Janovy (1978) indicate that plasmodium development starts at a site adjacent to the sinuses and capillaries of the gill lamellae, they do not agree with the observations made by McCraren et al. (1975) on the same parasite species, i.e. that infection starts from the capillaries of the gill lamellae. Therefore, the form designated by them as intralamellar corresponds to the location indicated as interlamellar by the present author. In the opinion of the present author, the photographs presented by McCraren et al. (1975) clearly show the intralamellar (intracapillary) location, and outgrowth of the plasmodium from the side of the gill lamellae into the interlamellar epithelium corresponds precisely to the type of development shown in this paper as 'intralamellar asymmetric type' in the example of the species Myxobolus bramae. The 'interlamellar' designation suggested by Current \& Janovy (1978) is even more confusing in a case where the authors obviously described a form of development within the gill filament (intrafilamental development). Although they specified a site of development linked with the blood vessels, presumably with the adventitia of the latter, it is the present author's opinion that vascular development is also more likely in that case.

In those few works where the researchers describing the species precisely indicated the location of the developmental site, most of the known species belonged to the intralamellar type of the gill locations proposed by the present author. Regarding Henneguya species, such a (lamellar) location has been reported by McCraren et al. (1975) for the Henneguya species studied by them, by Dyková \& Lom (1978) for H. psorospermica, by Cone (1979) for H. doori, by Shariff (1982) for H. shaharini, by Kalavati \& Narasimhamurti (1985) for H. waltairensis, by Haaparanta et al. (1994) and Molnár (1998) for $H$. creplini, and by Casals et al. (1997) for $H$. striolata. In addition to the findings published by Current \& Janovy (1978), the paper written by Obiekezie \& Enyenihi (1988) on H. chrysichthys contains data on the possible interlamellar location of Henneguya species. The intralamellar location seems to be the most common in the case of Myxobolus species as well, since the species Myxobolus dujardini, M. koi, M. hungaricus, $M$. bramae, $M$. macrocapsularis and M. margitae develop in this manner (Mitchell 1989, Yokoyama et al. 1997, Molnár \& Baska 1999, Molnár \& Székely 1999, Molnár 2000b), and the Мухоbolus species studied by Sanaullah \& Ahmed (1980) also follows that type of development. Data on interlamellar location (i.e. location in the epithelium be- tween the gill lamellae) were supplied by Molnár (1979) for the species M. pavlovskii, by Landsberg (1993) for M. centropomi, and by Molnár \& Székely (1999) for $M$. impressus. A unique case of development in the gill lamellae was reported by Cone \& Wiles (1985) for an unidentified species and by Masoumian et al. (1994) for $M$. persicus. Namely, these parasites formed a plasmodium between the endothelial and the epithelial layer of the gill lamella and, thus, the capillary bordered only by endothelium was discernible within the plasmodium.

In the case of development within the gill filament (filamental development), development within the blood path (vascular type of development) is also the most common, when the plasmodia are located in the afferent artery in which they form some small or a larger plasmodium. Of the Henneguya species, $H$. psorospermica, H. shaharini and $H$. creplini, which also have intralamellar forms according to Dyková \& Lom (1978), Shariff (1982) and Haaparanta et al. (1994), follow this type of development. It should be mentioned that in the case of the last mentioned species, Molnár (1998) observed only the latter location. Of the 2 thoroughly studied Thelohanellus species, T. pyriformis was found to develop in intralamellar and T. chilkensis in intrafilamental-vascular locations (Dyková \& Lom 1987, Kalavati \& Vaidehi 1991). Regarding other intrafilamental forms, observations on the chondreal type have been presented, apart from those reported in this paper, in the case of the species Myxobolus shadgani (Molnár et al. 1996). The cases reported by Paperna (1973), Sakiti et al. (1991), Bahri \& Marques (1996) and Yokoyama et al. (1997), where the tissue affinity of parasites with relatively well-defined locations was not discussed in detail, probably also corresponded to this type of development.

Thanks to the studies done by Lom \& Molnár (1983), as well as Kovács-Gayer \& Molnár (1983), on Myxobolus basilamellaris, the basifilamental type of development is better defined. Cases of infection of similar location have been reported by Paperna (1973), Cone \& Wiles (1985) and Bahri \& Marques (1996).

It has long been known that certain Myxobolus species select the cartilaginous matrix of the solid gill arch as the site of plasmodium development (Hoffman et al. 1965). In addition to $M$. cartilaginis, indicated as a typical species, M. sharpeyi, M. dossoui, M. sarotherodonis and $M$. intrachondrealis develop in this location (Hoffman et al. 1965, Sakiti et al. 1991, Molnár et al. 1996, Molnár 2000a). It is possible that M. ichkeulensis, described by Bahri \& Marques (1996), also colonises the cartilage of the gill arch. At the same time, Sakiti et al. (1991) indicated the adipose and connective tissue elements of the gill arch as a typical location for M. nokoueensis and M. microcapsularis. 
Studying the relationship between location on the gill and tissue affinity, it can be established that tissue affinity is definitely more important. While the same species may even develop in a filamental or lamellar location depending on fish size, plasmodium size, intensity of infection and other factors (Molnár \& Székely 1999), species of Myxosporea adapted to epithelium, cartilage, connective tissue, muscle tissue or endothelium have not been found to develop primarily in other tissues. Their possible occurrence in some other tissue, e.g. within a connective tissue capsule, is always the result of a secondary host reaction.

By comparing the diverse locations typical of the species described in the Results section with data reported in the literature on the site selection of the various species, it is concluded that in future species descriptions and pathological studies, the site of plasmodium development should be more precisely determined. According to this recommendation, it should be indicated in every case whether a given myxosporean species develops on the gill filaments, in the gill lamellae or in the gill arch. Also, reference should possibly be made to the tissue affinity of the parasite, i.e. to whether the given parasite develops in the epithelial, fibrous or cartilaginous tissues of the gill, or whether it is located within the vascular system. Up to this time, only very few authors have met this requirement, which was proposed by Molnár (1994) also in the case of other organs. Thus, for the majority of the existing species, data are available only on spore morphology. In view of the numerous uncertainties regarding indication of parasite location on the gill, a consistent terminology would be needed for the designation of gill structures, and first of all an accurate definition of the gill lamella is necessary. The author shares the opinion of Harder (1975), and suggests that the structures of the hemibranchia until now designated as 'primary lamellae' should be termed 'gill filaments', while for the designation of structures on the gill filaments the term 'gill lamellae' should be used instead of 'secondary lamellae'.

Acknowledgements. The author thanks Dr. Csaba Székely for his help in preparing digitalised photos. The study was made possible by a grant from the Hungarian Scientific Research Fund (project no. T 029200 and T 031755) and by financial support from the Fish Management Fund of the Ministry of Agriculture and Rural Development.

\section{LITERATURE CITED}

Bahri S, Marques A (1996) Myxosporean parasites of the genus Myxobolus from Mugil cephalus in Ichkeul lagoon, Tunisia: description of two new species. Dis Aquat Org 27:115-122

Bahri S, Ben Hassine OK, Marques A (1996) Henneguya sp.
(Myxosporea, Bivalvulida) infecting the gills of wild gilthead sea bream Sparus aurata L., from the coast of Tunisia. Bull Eur Assoc Fish Pathol 16:51-53

Casals G, Matos E, Azevedo A (1997) Some ultrastructural aspects of Henneguya striolata sp. nov. (Myxozoa, Myxosporea), a parasite of the Amazonian fish Serrasalmus striolatus. Parasitol Res 83:93-95

Cone DK (1979) Henneguya doori Guilford, 1963 (Myxosporida) of Perca flavescens in New Brunswick. Can J Zool 57:1785-1788

Cone DK, Wiles M (1985) Trophozoite morphology and development site of two species of Myxobolus (Myxozoa) parasitizing Catostomus commersoni and Notemigonus crysoleucas in Atlantic Canada. Can J Zool 63:2919-2923

Current WL, Janovy J (1978) Comparative study of ultrastructure of interlamellar and intralamellar types of Henneguya exilis Kudo from channel catfish. J Protozool 25:56-65

Dyková I, Lom J (1978) Histopathological changes in fish gills infected with myxosporidian parasites of the genus Henneguya. J Fish Biol 12:197-202

Dyková I, Lom J (1987) Host cell hypertrophy induced by contact with trophozoites of Thelohanellus pyriformis (Myxozoa: Myxosporea). Arch Protistenkd 133:285-293

Haaparanta A, Valtonen ET, Hoffmann RV (1994) Pathogenicity and seasonal occurrence of Henneguya creplini (Protozoa, Myxosporea) on the gills of perch Perca fluviatilis in central Finland. Dis Aquat Org 20:15-22

Harder W (1975) Anatomy of fishes. Parts I and II. E. Schweizerbart'sche Verlagsbuchhandlung (Nägele u. Obermiller), Stuttgart

Hoffman GL, Putz RE, Dunbar CE (1965) Studies on Myxosoma cartilaginis n. sp. (Protozoa: Myxosporidea) of centrarchid fish and a synopsis on the Myxosoma of North American freshwater fishes. J Protozool 12:319-332

Kalavati C, Narasimhamurti CC (1985) Histopathological changes in the gills of Channa punctatus Bl. infected with Henneguya waltairensis. Arch Protistenkd 129:199-202

Kalavati C, Vaidehi J (1991) A new myxosporidian Thelohanellus chilkensis n. sp. from the gills of the common carp, Labeo rohita in Chilka Lake, Orissa. Uttar Pradesh J Zool 11:73-78

Kovács-Gayer E, Molnár K (1983) Studies on the biology and pathology of the common carp parasite Myxobolus basilamellaris Lom et Molnár, 1983 (Myxozoa: Myxosporea). Acta Vet Hung 31:91-102

Landsberg JH (1993) Myxosporean parasites of common snook in Florida. J Aquat Anim Health 5:102-109

Lom J, Molnár K (1983) Myxobolus basilamellaris n. sp. (Myxozoa, Myxosporea) parasite of the gills of common carp (Cyprinus carpio L.). Folia Parasitol 30:1-3

Masoumian M, Baska F, Molnár K (1994) Description of Myxobolus karuni sp. n. and Myxobolus persicus sp. n. (Myxosporea, Myxozoa) from Barbus grypus of the River Karun, Iran. Parasit Hung 27:21-26

McCraren JP, Landolt ML, Hoffman GL, Meyer FP (1975) Variation in response of channel catfish to Henneguya sp. infections (Protozoa: Myxosporidea). J Wildl Dis 11:2-7

Mitchell LG (1989) Myxobolid parasites (Myxozoa: Myxobolidae) infecting fishes of western Montana, with notes on histopathology, sesonality, and intraspecific variation. Can J Zool 67:1915-1922

Molnár K (1979) Myxobolus pavlovskii (Achmerov, 1954) (Myxosporidia) infection in the silver carp and bighead. Acta Vet Acad Sci Hung 27:207-216

Molnár K (1994) Comments on the host, organ and tissue specificity of fish myxosporeans and on the types of their intrapiscine development. Parasit Hung 27:5-20 
Molnár K (1998) Taxonomic problems, seasonality and histopathology of Henneguya creplini (Myxosporea) infection of the pikeperch Stizostedion lucioperca in Lake Balaton. Folia Parasitol 45:261-269

Molnár K (2000a) Myxobolus intrachondrealis sp. n. (Myxosporea: Myxobolidae), a parasite of the gill cartilage of the comnmon carp, Cyprinus carpio. Folia Parasitol 47:167-171

Molnár K (2000b) Survey on Myxobolus infection of the bleak (Alburnus alburnus L.) in the River Danube and in Lake Balaton. Acta Vet Hung 48:421-432

Molnár K, Baska F (1999) Redescription of Myxobolus hungaricus Jaczó, 1940 (Myxosporea: Myxobolidae), a parasite of bream (Abramis brama). Acta Vet Hung 47:341-349

Molnár K, Székely Cs (1999) Myxobolus infection of the the gills of common bream (Abramis brama L.) in Lake Balaton and in the Kis-Balaton reservoir, Hungary. Acta Vet Hung 47:419-432

Molnár K, Masoumian M, Abasi S (1996) Four new Myxobolus spp. (Myxosporea: Myxobolidae) from Iranian barboid fishes. Arch Protistenkd 147:115-123

Obiekezie AI, Enyenihi UK (1988) Henneguya chrysichthyi sp. nov. (Protozoa: Myxozoa) from the gills of estuarine

Editorial responsibility: Wolfgang Körting,

Hannover, Germany catfish Chrysichthys nigrodigitatus (Lacépéde) (Pisces: Bagridae) in Nigeria. J Afr Zool 102:33-42

Paperna I (1973) Occurrence of Cnidospora infections in freshwater fishes in Africa. Bull Inst Fondam Afr Noire, A 35: 509-521

Roubal FR (1994) Histopathological and ecological aspects of Henneguya and Myxobolus (Myxosporea) infections in Acanthopagrus australis (Günther) (Pisces: Sparidae) from Moreton Bay, Australia. J Fish Dis 17:495-512

Sakiti N, Blanc É, Marques A, Bouix G (1991) Myxosporidies (Myxozoa, Myxosporea) du genre Myxobolus Bütschli, 1882 parasites de poissons Cichlidae du lac Nokoué au Bénin (Afrique de l'Ouest). J Afr Zool 1:173-186

Sanaullah M, Ahmed ATA (1980) Gill myxoboliasis of major carps in Bangladesh. J Fish Dis 3:349-354

Shariff N (1982) Henneguya shaharini sp. nov. (Protozoa: Myxozoa), a parasite of marble goby, Oxieleotrix marmoratus (Bleeker). J Fish Dis 5:37-45

Yokoyama H, Inoue D, Kumamaru A, Wakabayashi H (1997): Myxobolus koi (Myxozoa: Myxosporea) forms large- and small-type 'cysts' in the gills of common carp. Fish Pathol $32: 211-217$

Submitted: April 24, 2001; Accepted: September 7, 2001 Proofs received from author(s): March 13, 2002 